\title{
Divorce Decision-Making in Javanese Women: A Review from Social, Cultural, and Gender Perspective
}

\author{
Devi Puspitasari ${ }^{1 *}$, Jatie. K. Pudjibudojo ${ }^{2}$, Hartanti ${ }^{3}$ \\ ${ }^{1}$ Doctoral Program in Psychology, UBAYA, Surabaya Indonesia \\ ${ }^{2}$ Doctoral Program in Psychology, UBAYA, Surabaya Indonesia \\ ${ }^{3}$ Doctoral Program in Psychology, UBAYA, Surabaya Indonesia \\ *Corresponding author.Email: devipuspitasari31@gmail.com
}

\begin{abstract}
Divorce phenomenon all across the globe has shown significant increases, which also happens in Indonesia. Based on records from the Supreme Court, there were 480.618 divorces cases in 2019, with 25\% cases filed by the husbands and $75 \%$ cases filed by the wives. This study aims to identify divorce decision making process in Javanese women from cocial, cultural, and gender perspective using literature review and survey. The survey was conducted because the literature on this topic was limited. Survey was conducted by an author to 78 Javanese women aged 20-5- years have filed divirce to their husband and have children shows results that support the previous research. Criteria for Javanese women here are born from Javanese ethnic or descendants of Javanese people, have Javanese identity like a name that still uses Javanese idiom, practising Javanese obsolete cultural values, and also live in a family that still upholds this Javanese tradition. The literature reviews shows result that gender role still plays a major part, where women is a "guard" which responsible for every house chores, child bearing and obey her husband, makes women often got blamed when divorce happened and treated as incapable of taking care her husband's dignity and her marriage life. The survey results show these women considered external factors such as children, family reputation, and social status (stigma of being a widow). A conclusion that could be taken from this literature review is that it is not easy to file a divorce for Javanese women, which eventually made them stay in their marital conflict to avoid divorce, because their Javanese culture really upholds marriage value.
\end{abstract}

Keywords: Divorce Decision Making, Javanese women, Social Perspective.

\section{INTRODUCTION}

Married couples certainly hope for a harmonious and lasting marriage until the end of their life, but in the marriage journey, conflicts often arise that cannot be resolved. The inability to resolve marital conflicts continues, causing husband and wife to take the solutions with divorce. Marriage dissolution can be caused by death, divorce and by court decision (UU No. 1 tahun 1974). The divorce phenomenon has shown an increase worldwide, this also happens in Indonesia. In Indonesia, based on data cited www.detik.com [1] from the website of the Supreme Court (MA) in 2020, divorce rate from 2015 to 2019 shows an increase. In 2017 there were 374,400 divorce cases, while in 2019 increased to 480,618 cases. The data also shows that the number for cerai gugat from the wife side is higher every year than the cerai talak from husband side. In 2018 there were
307,700 cerai gugat, while the number cerai talak was 111,400 [1]. In East Java, the Surabaya High Religious Court recorded that divorce rate throughout 208 reached around 121,000 cases and was among the highest for divorces. In Surabaya, there were 5,235 divorce cases throughout 2018, of which 3,785 filed for cerai gugat (www.jpnn.com) [2].

Proulx [3] has conducted research to investigate psychological experiences and triggers for divorce decisions by reviewing the social exchange theory developed by Albert \& Kunz [4] which states that the marital dissolution or divorce present a rational choice model by comparing costs and benefits and neglected affection elements. Proulx found that self-development (personal growth) and self-concept as a struggle from self-conflict to strengthen divorce decision-making.

Furtado, Marcen \& Sevilla-Sanz [5] conducted a study on immigrants from Europe aged 25-64, who 
arrived in the United States, the study aims to examine the role of the culture from the origin country in determining divorce decisions. The finding is that the culture of the country of origin is very important even though this study has limitations which do not explain at first, second or third marriage but divorce having stronger impact on decision making for women than men, which shows divorce is potentially influenced by gender.

Qualitative study that specifically discusses about divorce decision making and the stages it takes, one of which was conducted by Fackrell [6] with the findings that not necessarily a bad marriage encourages someone to divorce because evey marital relationship has it own characteristics and the thought process in making a divorce decision is very confusing, therefore someone need help from others to get out from this confusing thing called a "vast wilderness". Vast Wilderness is the very confusing events and there is seven keys factor that affect divorce decision-making which is impact on emotions and physicality, children, friendship, and good memories with a partner, religion, prayer and hope, commitment to marriage, social impact and support from family and friends, finances.

Individu who is in the middle of making divorce decision has a different experience in each process. Harris, et al [7] in their studies found that the clarity of the decision to divorce can be influenced by important events and the clarity fluctuates and it takes time to find it. Decision making for divorce also requires the role of trust (confidence) in order to believe that the final decision is the right and best.

\subsection{Javanese Women}

The selection of Javanese women can be seen based on the boundaries of Javanese society, namely people who are born from Javanese ethnicity or descendants of Javanese people from previous generations, have a Javanese identity, for example, names that still use Javanese idioms, practice the traditional values of Javanese ancestral culture with their own awareness [8] and live with family environment, most of which still uphold Javanese traditions.

The image of the ideal Javanese woman is one who is graceful, obedient, and subservient to men. Since childhood, Javanese women have been trained to prepare for marriage with advice that women should be able to cook, dress up, so that they must please their husband and children [9]. According to Budiati [10], the concept of Javanese women is also implied in various literary works such as serat-serat, wayang and modern literature, for example Panitisastra and Candrarini, that explains the concept of Javanese women as someone who is loyal to en, good at dressing up, good at serving the wishes of men and paying attention to in-laws.

According to Javanese women, the concept of dadi wong is not only in material aspects, but there are religions, morality, ethics, psychology, and socioculture, so the Javanese success is not only related to the economy, but mainly cultural attributes, especially Javanese culture [10]. The concept of Javanese cultural prosperity in relation to the role of women is when women become wives and mothers as the main positions in the family and society, so that creating a harmonious marriage is important for Javanese women

\subsection{Divorce Decision-Making}

Divorce is the culmination point of the accumulation of various problems so that a couple who is going to divorce is marked by a separation process. Bohannon in Kaslow [11] divides the stage in describing the complexity in the occurrence of divorce is: 1) emotional separation, the couple experiences the peak of stress and realizes that their marriage cannot be continued and considers separation; 2) legal separation, husband or wife discussing divorce and contacting lawyer so through procedure to end the marriage; 3) economic separation, the distribution of assets, property, child support and those related to finance; 4) co parental divorce, which is considering childcare patterns, whether to follow the father or mother after the divorce; 5) reaction from family and friends; 6) physical separation, namely adjustment to being single, does not have a relationship with an exhusband or wife.

Vaughn [12] discusses in detail the stages of divorce decision making from the point of view of the initiator (who took the initiative to divorce). According to Vaughn, dividing the decision to separate from partner including divoce in twelve stages called "Uncoupling". These stages are: 1) secrets, 2) display of discontent, 3) middle of transition, 4) signals, secrets and collaborative coverup, 5) the breakdown of cover-up, 6) trying, 7) the 
initiator's advantage, 8) going public, 9) the partner's transition, 10) uncoupling, 11) transition rituals, 12) on telling secrets to a strangers). Her study

\subsection{Divorce Decision-Making in Javanese Women}

Javanese women are faces with a difficult choice to decide whether to divorce or remain married. In Javanese culture, socially patriarchal views perpetrators of divorce, especially women (divorced women) and considers it a "disgrace or nightmare" for extended families. Divorced women are considered "ex-husband" and "less good women". In divorce cases, women are often the guilty party because they are considered 'incompetent", lack patience in dealing with problems and cannot maintain the good name of the family [13].

The courage of Javanese women for making the decision to divorce is a behaviour that breaks Javanese socio-cultural values. In fact, many women who have problems in marriage choose to remain married even though they are independent financially. Women decide to divorce because of the awareness of their rights as wives which are violated by their husband, they said that they have given the husband the opportunity to correct mistakes but the husbands are not willing to change, so divorce is "forced" to be made because the choice to keep the marriage is considered more painful and torturous [12].

Javanese women in decision making for divorce will experience emotional challenges due to the burden of roles in the family and also social norms that consider divorcing women to be a disgrace. Confusion, consideration, doubt and intrapersonal conflict that affect her and her family cause many Javanese women to experience marital problems and conflicts, choosing to stay in marriages that cause suffering because of worries about being divorced women.

Literature related to the divorce decisionmaking process for Javanese women is limited especially for Javanese women, accordingly the authors conducted a survey by distributing questionnaires related to the divorce decision-making process. The purpose of this study is to determine the causes of divorce and the various considerations in making a divorce decision.

\section{METHOD}

\subsection{Literature Review}

The method used is literature review and survey as additional data to determine decision making of divorce. Literature review with keywords "divorce decision making process, divorce decision making, marital dissolution decision making, Javanese women divorce decision making, Javanese women and divorce, divorce decision making process). The studies on divorce decision making found there were 15 studies and the study that examined the divorce decision -making process for Javanese women found only one study by Rizki [13] in Surakarta.

\subsection{Survey}

The survey was conducted to Javanese women by filling out a questionnaire containing 18 questions about what considerations they had when deciding to divorce. The questionnaire consists of closed and open questions so that they can explain more fully.

\section{RESULT}

\subsection{Number and Source of Articles}

The selected studies with the theme of the divorce decision making process were summarized based on the number of subjects and location as well as the research finding. Studies have also been conducted in America and Asia as well Indonesia.

From the literature results obtained data from studies conducted in America, Asia, including Indonesia. Research by Fackrell [6] found that someone who is at the crossroads of divorce needs time and help from others to get out of deep confusion or what is called a "vast wilderness" with seven main considerations, namely physical and emotional impacts, children, friendship and good memories with spouse, religion, commitment to marriage, social and financial impact. Women decide to sue for divorce as the culmination point of accumulated problems during marriage. Proulx's [3] study found that American women have the courage to sue for divorce after trying to fight and reconcile marital conflicts but unsuccessfully. Openness to join counseling groups and consult with professionals brings about a change in the self-concept that one must be able to be 
responsible for oneself without depending on others. Proulx [3] explains that the stage in making a divorce decision always begins with dissatisfaction and disappointment with the partner because the marriage does not bring any benefits.

Harris, et al [14] conducted a study on men and women with an average age of 40 years, married for 13 years and had the idea of divorcing. The findings of this study are that someone decides to divorce with the clarity and belief that the decision made is right and the best. This clarity and confidence are closely related to the joyful moments of marriage and to think that marriage does not only contain suffering. The findings are in accordance with Crabtree, et al [15] who conducted research on white men and women in America, black and mixed people, with a marriage age of 1 year who had thoughts of divorce for the last 6 months, that marriage does not all contain suffering, but love and happiness that have been being obtained are an important consideration in deciding whether or not to divorce.

A scientist who also examines divorce decision making is Kanewischer [16] with a feminist phenomenology perspective, findings concluded that the consideration of women to remain in marriage so far is the husband's commitment to change and related to children, the love that still exists and religion. Religious considerations in making divorce decisions are in accordance with research conducted by Bell, et al [17] about men and women with an average marital age of 13 who thought about divorce in the past 6 months. The finding is that religion and spirituality greatly influence divorce decision making. Religion causes a person to fall into confusion because someone believes that marriage is destiny and staying married is morally right, but religion also makes them believe that God does not want His people to suffer and be treated badly.

In Asia, research on divorce decision making in women was conducted in Israel by HajYahia [18] on 15 women who experienced domestic violence, the findings are women are brave enough to sue for divorce because they are concerned about children's psychology due to seeing and feeling domestic violence. The decision to divorce the husband_also received social support from the family (mother, brother, sister, friend) and legally received assistance from community services such as the police and legal services. Research was also conducted in Tehran, the capital city of Iran by Khorasani \& Ghiasvand [19] on 20 women who were divorced at least the last 6 months and had children. The reason for women suing for divorce is due to unequal roles in marriage, not being fulfilled properly and being considered unable to carry out household duties. These events frustrate women, but when they divorce there are worries about being a widow and a lack of family support. Patriarchal culture causes a heavy burden related to fulfilling economic needs after bearing the status of a widow and a negative label related to sexuality.

Table 1. Table Review

\begin{tabular}{|c|c|c|c|}
\hline Researcher & Country of origin & Sample (n) & Purpose \\
\hline$[7]$ & America & $\begin{array}{c}156 \text { people (30 men and } \\
126 \text { women) }\end{array}$ & $\begin{array}{c}\text { Exploring the triggers for divorce decision and } \\
\text { understand the thought process of serious } \\
\text { consideration in divorce }\end{array}$ \\
\hline$[2]$ & Israel & $\begin{array}{c}18 \text { people (3 men and 15 } \\
\text { women) }\end{array}$ & $\begin{array}{c}\text { Provides a qualitative assessment of the factors that } \\
\text { enable to decide on divorce and simple } \\
\text { interventions that can aid decision making at all } \\
\text { stages of the divorce process }\end{array}$ \\
\hline$[1]$ & Iran & 20 women & $\begin{array}{c}\text { Investigate the nature of the divorce decision } \\
\text { process by women who divorce and have children }\end{array}$ \\
\hline$[5]$ & Indonesia & $\begin{array}{c}210 \text { people (3 men, 207 } \\
\text { women })\end{array}$ & $\begin{array}{c}\text { Examine the description of the process of making } \\
\text { divorce decision }\end{array}$ \\
\hline
\end{tabular}




\subsection{Survey}

Survey showed Javanese women filed for divorce between the ages of 30-40 years (45\%), ages 20-30 years $(44 \%)$. The survey found that Javanese women in making decisions on divorce consider children $(59 \%)$, social status $(9 \%)$, family $(9 \%)$, finances $(6,4 \%)$, religion $(4 \%)$, threats $(1,3)$, children and social status $(1,3 \%)$ and anxiety about living alone $(1,3)$. Respondents in the survey expressed concern regarding the lack of love from fathers for their children, child custody and views of being a "broken home" child, but on the other side they did not want their children to see their parent's conflicts. They also consider families who disagree because the child is still young and the status of a widow will affect the good name of the family. About social status, there is a worry with the stigma of being a divorced woman, it can affect the future if they find a new partner and the partner's family make a question about her status. Financial problems are also a consideration, especially for respondents who are unemployed. Religion is a concern, but they feel more sinful if that are unable or unwilling to carry out the role of wife.

\subsection{Discussion}

The studies that the authors found about the divorce decision-making process were mostly conducted in America and Asia. The author finds it difficult to find studies related to the topic of the divorce decision-making process in Indonesia because almost all of the studies found only examine the factors that cause divorce. Research on the process of divorce decision-making has in common that it involves emotional and physical impacts and creates confusion, doubt and chaos. The difference in findings between research in America and in Asia, especially in Iraq, Iran, and Indonesia is that America does not really consider the social status of being a widow, while in Asia, social status is one of the crucial things in making divorce decisions.

The author focuses on the topic of the divorce decision-making process for Javanese women, but so far only found one research article conducted in Surakarta. The survey conducted by the author apparently supports the results of studies that have been conducted in Asia, namely that the biggest consideration for women in making the decision to divorce is children, social status related to the stigma of widows and the dignity of extended families. From the survey results, it turns out that the respondents don't really consider financial needs and have the courage to sue for divorce even though they don't work. The survey results also found that respondents who were economically independent took years before they finally dared to sue for divorce. Religious factors are also not important in making divorce decisions. This is very surprising because Javanese culture is still thick with religious norms that allow it even though it is a hated act.

\subsection{Conclusion}

Based on a study of the divorce decisionmaking process, it can be concluded that a person who is at the crossroads of a divorce decision experiences confusion, doubt, and confusion both physically and emotionally. The considerations that arise in the process of making a divorce decision are children, religion, social status and financial. The limitations of literature on the process of decisionmaking for divorce for Javanese women prompted the author to conduct a survey on this topic which found that children, social status, extended family, finance and religion were the five considerations for suing for divorce. Children's consideration is attention to mental processes and development due to losing their father figure, being labelled a "broken home" child and engaging in deviant behaviour. Consideration of social status is the status of widows which is still viewed negatively by society and often receives discrimination. The family's consideration is that the status of a widow undermines the dignity of the parents and is a "disgrace" to the extended family. Financial considerations arise from respondents who do not work so that there are concerns related to children's education, while from a religious perspective, divorce is an act that is hated by God.

\section{AUTHORS' CONTRIBUTIONS}

The Author (1) one author who has an idea and a topic to be researched. The author also searches to find articles related to the topic and at the same time conducts a survey of divorced Javanese women. 
The role of the Author (2), give suggestions and input regarding the theory that is the basis of the topic, and also evaluate article writing so that it is more clearly read.

While the Author (3) in provide suggestions as well as follow any progress and also evaluate the questions in the survey questionnaire.

\section{ACKNOWLEDGMENTS}

The authors thank you for the attention and appreciation for writing this article and this is dedicated to adding insight into divorce for women.

\section{REFERENCES}

[1] Khofifah. Siapkan lembaga konsultasi untuk tekan angka perceraian. 2018. Available from http://news.detik.com/khofifah-siapkanlembaga-konsultasi-untuk-tekan-angkaperceraian

[2] jpnn.com [Internet]. Setahun ada tambahan 5.235 janda di Surabaya karena perceraian. 2019. Available from

https://www.jpnn.com/news/setahun-adatambahan-5235-janda-di-surabaya-karenaperceraian.

[3] G. M. Proulx. The decision making process involved in divorce. A critical incident study. Thesis. Department of Counseling Psychology. The University of British Columbia. 1991. DOI: $10.14288 / 1.0053643$

[4] S. L. Albrecht., P. R. Kunz. The decision to divorce: A social exchange perspective. J. Divorce. 3 (1980) 319-337.

[5] D. Furtado., M. Marcen., A. Sevilla-Sanz. Does culture affect divorce decision? Evidence from European immigrants in the US. Discussion Paper. No. 5690. Department of Economics. University of Connecticut. 2011.

[6] T. Fackrell. Wandering in Wilderness: A ground theory study of the divorce or reconciliation decision making process. All Theses and Dissertations. 2012. Brigham Young University. Available from https://scholarsarchieve.byu.edu/etd/3136
[7] S.M. Harris, S.A. Crabtree, N.K. Bell, S.M. Allen, K.M. Roberts. Seeking clarity and confidence in the divorce decision making. J. Divorce Remarriage. 58(2). 2017. Montana State University.

http://www.tandfonline.co,/10.1080/105025556.2 016.1268015

[8] D. P. K. Putri., S. Lestari. Pembagian peran dalam rumah tangga pada pasangan suami istri Jawa. J. Penel. Humaniora. 16(1) (2015) 72-85.

[9] N. Nurmila. Pengaruh budaya patriarki terhadap pemahaman agama dan pembentukan budaya karsa. J. Sos Bud dan Keislaman. 23(1) (2015). DOI: 10.19105/karsa.v23i1.606.

[10] A. C. Budiati. Aktualisasi diri perempuan dalam sistem budaya Jawa (persepsi perempuan terhadap nilai-nilai budaya Jawa dalam mengaktualisasikan diri). Pamator. 3(1) (2010) 51-59.

[11]. F. W. Kaslow. Stages of divorces: A psychological perspective. Villanova Law Review. Published by Villanova University Charles Widger School of Law Digital Repository. 25(4) (1980) 718-751

[12] D. Vaughn. Uncoupling,. Turning points in intimate relationships. Vintage Book Edition. New York. Oxford University Press, Inc.1986.

[13] R. R. Rizki, T. R. Andayani. Peran kearifan dalam pengambilan keputusan untuk bercerai pada istri yang mengajukan gugatan cerai di pengadilan agama. Wacana J. Psiko. 3(21) (2011). DOI: 10.13057/wacana.v3il.44

[14] S. M. Harris, S.A. Crabtree, N.K. Bell, S.M. Allen, K.M. Roberts. Seeking clarity and confidence in the divorce decision making. J. Divorce Remarriage. 58(2) (2017). http://www.tandfonline.com/10.1080/1050255 6.2016 .1268015

[15] S. A. Crabtree. S.M. Harris, N.K. Bell, S. Allen, K.M. Roberts. The roles of love and happiness in divorce decision making. J. Divorce Remarriage. 2018. DOI: 1080/10502556.2018.1466254 
[16] E. J.W. Kanewischer. Deciding not to un-do-the "I Do": A qualitative study of the therapy experiencer of women who consider divorce but decide to remain married. A Dissertation Submitted to the Faculty of the Graduate School of the University of Minnesota. 2012.

[17] N. K. Bell, S.M. Harris, S.A. Crabtree, S.M. Allen, K.M. Roberts. Divorce decision making and the divine. J. Divorce Remarriage. 59(1) (2018) 37-50.

[18] M.M Haj-Yahia., D. Eldar-Avidan. Formerly battered women: A qualitative study of their experiences in making decision to divorce and carrying it out. J. Divorce Remarriage. 36(1/2) (2001) 37-65.

[19] S. A. Khorasani., A. Ghiasvand. Women's decision to divorce in light of failure in marital status and dignity. J. Divorce Remarriage. 2017. DOI: 10.1080/10502556.2017.1403822 